\title{
Escalating environmental summer heat exposure-a future threat for the European workforce
}

\author{
Ana Casanueva ${ }^{1,2}$ D $\cdot$ Sven Kotlarski ${ }^{1} \cdot$ Andreas M. Fischer $^{1} \cdot$ Andreas D. Flouris $^{3} \cdot$ Tord Kjellstrom $^{4,5} \cdot$ Bruno Lemke $^{6} \cdot$

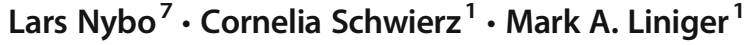

Received: 3 June 2019 / Accepted: 23 February 2020 / Published online: 23 March 2020

(C) The Author(s) 2020

\begin{abstract}
Heat exposure constitutes a major threat for European workers, with significant impacts on the workers' health and productivity. Climate projections over the next decades show a continuous and accelerated warming over Europe together with longer, more intense and more frequent heatwaves on regional and local scales. In this work, we assess the increased risk in future occupational heat stress levels using the wet bulb globe temperature (WBGT), an index adopted by the International Standards Organization as regulatory index to measure the heat exposure of working people. Our results show that, in large parts of Europe, future heat exposure will indeed exceed critical levels for physically active humans far more often than in today's climate, and labour productivity might be largely reduced in southern Europe. European industries should adapt to the projected changes to prevent major consequences for the workers' health and to preserve economic productivity.
\end{abstract}

Keywords Heat exposure $\cdot$ Heat stress $\cdot$ Climate change $\cdot$ Wet bulb globe temperature $\cdot$ Labour productivity

Communicated by Wolfgang Cramer

Electronic supplementary material The online version of this article (https://doi.org/10.1007/s10113-020-01625-6) contains supplementary material, which is available to authorized users.
Ana Casanueva

ana.casanueva@unican.es

Sven Kotlarski

sven.kotlarski@meteoswiss.ch

Andreas M. Fischer

andreas.fischer@meteoswiss.ch

Andreas D. Flouris

andreasflouris@gmail.com

Tord Kjellstrom

kjellstromt@yahoo.com

Bruno Lemke

bruno.lemke@nmit.ac.nz

Lars Nybo

nybo@nexs.ku.dk

Cornelia Schwierz

cornelia.schwierz@meteoswiss.ch
Mark A. Liniger

mark.liniger@meteoswiss.ch

1 Federal Office of Meteorology and Climatology MeteoSwiss, Zurich, Switzerland

2 Meteorology Group, Dept. Applied Mathematics and Computer Science, University of Cantabria, Santander, Spain

3 FAME Laboratory, Department of Exercise Science, University of Thessaly, Karies, Trikala, Greece

4 Centre for Technological Research and Innovation (CETRI), Limmasol, Cyprus

5 Australian National University, Canberra, Australia

6 Nelson-Marlborough Institute of Technology, Nelson, New Zealand

Department of Nutrition and Exercise Sciences, University of Copenhagen, Copenhagen, Denmark 


\section{Introduction}

Mean surface temperature as well as the frequency and duration of heat waves have increased in the last decades in Europe (IPCC 2013), in particular in the south-east of the continent (Pogačar et al. 2018; Barriopedro et al. 2011; Morabito et al. 2017). Also, future heat waves are very likely to be more frequent and longer-lasting (IPCC 2013), mainly as a direct consequence of the increase in mean temperatures (Schär, et al. 2004; Fischer and Schär 2010). Those changes relate to increasing environmental heat exposure throughout the twenty-first century (Willett and Sherwood 2010; Zhao et al. 2015; Knutson and Ploshay 2016; Coffel et al. 2018; Li et al. 2018; Matthews 2018) which in turn might have an effect on mortality, well-being and labour productivity (Dunne et al. 2013; Kjellstrom et al. 2018; Mora et al. 2017; Flouris et al. 2018; Levi et al. 2018; Moda et al. 2019). The combination of environmental heat exposure and internal heat production generated from metabolic processes results in heat stress (Xiang et al. 2014). Air temperature is an important aspect, but all relevant environmental factors should be considered in order to provide improved early warning systems and future projections of heat exposure (Li et al. 2018; Matthews 2018). Under high-airtemperature situations, the only means for the body to remain within healthy temperature limits is through loss of heat via sweat evaporation (Kenny and Flouris 2014). However, high air humidity and lack of wind limit sweat evaporation and, hence, heat dissipation that, enhanced by intense solar radiation, leads to a rise in core body temperature (Parsons 2014). This may increase the risk of heat-caused illnesses such as heat cramps, heat syncope, heat exhaustion and heat stroke (Koppe et al. 2004).

Excessive heat exposure greatly affects not only the more vulnerable population groups (such as children and elderly people) but also those performing physically demanding activities like physical exercise (Junge et al. 2016) or work (Kjellstrom et al. 2009a). Improper clothing (due to personal work protection or cultural reasons) and/or absence of cooling systems exacerbates the adverse heat conditions even further (Kjellstrom et al. 2009b). Environmental heat is a key factor for the workforce, and it is associated with a reduction of physical productivity (Wyndham 1969; Kjellstrom et al. 2009b; Sahu et al. 2013; Ioannou et al. 2017). Therefore, a better knowledge of environmental heat exposure is decisive for protecting population health and is a key management information for industries to plan labour activity and anticipate changes in productivity.

There is a large number of documented indices (see, e.g. Coccolo et al. 2016, Burgstall et al. 2019) that quantify heat exposure by combining several meteorological drivers (most of them based just on air temperature and humidity, and a few include wind speed and solar radiation). In the present work, heat exposure is represented by the wet bulb globe temperature (WBGT), since (1) it is the most widely used index to assess heat stress on working people, (2) it can be calculated from standard meteorological parameters including also the effect of solar radiation and (3) it can be interpreted via international labour standards (ISO 1989, 2017). Employing the purely meteorology-based WBGT, this work paves the way for further studies based on other heat indices that potentially involve physiological criteria and that are relevant for other impact analyses (e.g. mortality, Mora et al. 2017).

Previous works on climate projections of environmental heat accounted for shaded conditions only and were developed with a global perspective (Willett and Sherwood 2010; Zhao et al. 2015; Knutson and Ploshay 2016; Coffel et al. 2018; Li et al. 2018; Brouillet and Joussaume 2019), highlighting the dangerous conditions in densely populated areas (e.g. Southeast Asia, Africa), but the detailed impact in Europe is often overlooked. In order to assess future changes in environmental heat exposure on a pan-European level, the comprehensive and state-of-the-art regional climate model (RCM) ensemble of the EURO-CORDEX initiative (Jacob et al. 2014; Kotlarski et al. 2014) is exploited in the present work. Model simulations are statistically adjusted to the local, site-specific climate at more than a thousand locations in Europe. The effect of the projected changes of environmental heat on occupational settings is shown as an example of application.

This work is structured as follows. The data and study methods are described in 'Data and methods'. 'Results' shows climate change projections of heat exposure and impacts on labour productivity in Europe. The main conclusions are summarized in 'Discussion and conclusions'.

\section{Data and methods}

\section{Wet bulb globe temperature and derived indices}

Two implementations of the WBGT are used in order to account for shaded ( $\mathrm{WBGT}_{\text {shade }}$ ) and sunny conditions $\left(\mathrm{WBGT}_{\text {sun }}\right) . \mathrm{WBGT}_{\text {sun }}$ (Liljegren et al. 2008) takes into account air temperature, dew point temperature, wind speed and solar radiation, whereas $\mathrm{WBGT}_{\text {shade }}$ is a simplified version based on air temperature and dew point temperature only (Bernard and Pourmoghani 1999), assuming a wind speed of $1 \mathrm{~m} / \mathrm{s}$, which is the apparent wind created by limb and torso for actively working people (i.e. equivalent to a slow walk), and no heat from radiation. The reader is referred to Lemke and Kjellstrom (2012) for a comparison of WBGT calculations and the detailed formulations. Those two versions 
of WBGT have been implemented in the $\mathrm{R}$ package HeatStress, ${ }^{1}$ under license GPL-3.

In this work, we target daily maximum heat exposure, obtained from the daily values of the input variables that enhance it, i.e. daily maximum air temperature and solar radiation and daily mean dew point temperature wind speed (see Annex A and Fig. S1 in the Supplementary Material). Several derived indices accounting for heat exposure risk are obtained from the daily WBGT values and presented for the summer season for the sake of brevity (Table 1). We acknowledge that the chosen metric (daily mean or maximum) and temporal aggregation (monthly, seasonal) have implications on the resulting indices, as discussed in the Supplementary Material (Annex B and Table S1).

Several organizations (ISO 2017; American Conference of Governmental Industrial Hygienists (ACGIH) (2016)) have defined reference and critical values of WBGT for different classes of metabolic rate (resting, low, moderate, high and very high), clothing, and considering whether a person is acclimatized or not. The application of the different WBGT reference values allows analysing heat stress for resting conditions, elderly people or vulnerable groups of the population. In this work, for the sake of brevity, we focus on exposure limits assuming moderate work intensity (300-350 W) for an unacclimatized $\left(26^{\circ} \mathrm{C}\right)$ and acclimatized $\left(28^{\circ} \mathrm{C}\right)$ worker (see NIOSH (2016) for a comparison of thresholds for different exposure limits as adopted by several international institutions). This way the uncertainty due to the acclimatization state of the workers is also considered. These reference values are a conservative choice since they imply protecting most of the workforce (depending on the individual conditions, one worker can be vulnerable to suffer from heat stress under lower or higher WBGT values); therefore, they should be understood as an example of application. For the sake of conciseness, we will refer to WBGT as overall environmental heat exposure and conditions with WBGT above $26{ }^{\circ} \mathrm{C}$ as moderate heat risk and above $28^{\circ} \mathrm{C}$ as high heat risk throughout the manuscript.

There are a few approaches to estimate productivity loss at country and individual levels. For instance, Sahu et al. (2013) and Junge et al. (2016) quantify productivity as production and power output, respectively, whereas Ioannou et al. (2017) introduced a time-motion analysis to assess the effects of workplace heat on productivity and labour effort. Regardless of the method used, a graduate loss of productivity (UNDP 2016) and economic impact (Orlov et al. 2019) with increasing thermal exposure is evident. Exposure-response relationships are usually established between hourly heat exposure and productivity (e.g. WBGT above $31{ }^{\circ} \mathrm{C}$ under moderate work implies $25 \%$ reduction of labour productivity in one hour for specific epidemiological studies, Kjellstrom

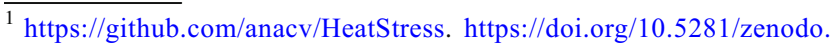
3264929 et al. 2018). We approximated hourly values with daily mean and maximum WBGT values following the $4+4+4$ method (Kjellstrom et al. 2018), which is a good approximation compared to more complex and computationally intense temperature models (Bilbao et al. 2002). This method assumes the daily maximum WGBT value during the 4 central hours of the day (12-16 h), the daily mean WBGT during $4 \mathrm{~h}$ in the early morning (8-10 h) and the early evening (18-20 h), and the remaining $4 \mathrm{~h}$ in between are approximated with the average of daily mean and maximum values (10-12 $\mathrm{h}$ and 16$18 \mathrm{~h}$ ). Daily mean values of WBGT are derived from daily mean values of all the input parameters. Combining the hourly WBGT with the exposure-response curve from ISO (1989), we obtain the percentage of hours lost due to heat exposure, assuming that the workers are potentially active $8 \mathrm{~h}$ /day (from 9 to $17 \mathrm{~h})$.

\section{Observational data}

Due to the lack of dense observational datasets for all meteorological parameters needed in the WBGT calculation, daily station data from different data sources are used. First, we consider the European Climate Assessment \& Dataset (ECA\&D, Klein Tank et al. (2002)), which is the basis for the E-OBS gridded product (Haylock et al. 2008) and contains series of daily observations at meteorological stations throughout Europe and North Africa. Daily series for maximum and mean temperature, relative humidity and wind speed were downloaded in June 2016 from www.ecad.eu.

Second, due to the low station density for non-standard parameters (e.g. humidity, wind), we combine the available ECA\&D stations with the Global Surface Summary of the Day (GSOD, Smith et al. 2011) dataset which is based on data exchanged under the framework of the World Meteorological Organization (WMO) World Weather Watch Program. Daily series of daily mean and maximum temperature and daily mean dew point temperature and wind speed were downloaded from ftp://ftp.ncdc.noaa.gov/pub/data/gsod/ in July 2016.

For both products, only the stations with less than $20 \%$ of missing data in the period 1981-2010 for the three variables were considered (Fig. S2) after an additional filter for outliers. The two datasets were combined into a single one, and for the station locations where ECA\&D and GSOD are available, priority was given to ECA\&D. We additionally made use of the station set from the SwissMetNet ${ }^{2}$ (SMN) dataset over Switzerland, which is provided and maintained by MeteoSwiss. Summarizing, the finally merged dataset considered in this work consists of 1370 European stations, coming

\footnotetext{
2 http://www.meteoswiss.admin.ch/content/dam/meteoswiss/en/MessPrognosesysteme/Bodenstationen/Automatisches-Messnetz/doc/ SwissMetNet_The_MeteoSwiss_Reference_Monitoring_Network.pdf
} 
Table 1 Summary of the Wet Bulb Globe Temperature (WBGT) derived indices considered throughout the manuscript. Calculations are based on daily maximum values of WBGT. All the indices are calculated for heat exposure in shaded ( $\mathrm{WBGT}_{\text {shade }}$ ) and sunny conditions
$\left(\mathrm{WBGT}_{\text {sun }}\right)$. Some indices represent intensity (I), whereas others characterize frequency (F) of heat exposure (column "Type"). WBGTx $3 d$ is merely introduced as a smoothed version of WBGTx1d for the time series plots in Fig. 1

\begin{tabular}{|c|c|c|c|}
\hline Abbreviation & Definition & Type & Unit \\
\hline WBGTmean & Summer (JJA) mean WBGT & I & ${ }^{\circ} \mathrm{C}$ \\
\hline WBGTx1d & Summer single-day maximum WBGT & I & ${ }^{\circ} \mathrm{C}$ \\
\hline WBGTx3d & Summer maximum of moving 3-day average WBGT & I & ${ }^{\circ} \mathrm{C}$ \\
\hline WBGTg26 & Number of summer days with WBGT $>26^{\circ} \mathrm{C}$ & $\mathrm{F}$ & Days \\
\hline WBGTg28 & Number of summer days with WBGT $>28^{\circ} \mathrm{C}$ & $\mathrm{F}$ & Days \\
\hline
\end{tabular}

from 351 ECA\&D stations (Fig. S2, green), 976 GSOD stations (blue) and 43 SMN stations (red).

In order to cover all European stations for which the rest of the variables was available, we consider satellitederived daily downward surface solar radiation data (SARAH from the CMSAF surface radiation dataset, Pfeifroth et al. 2017) that are based on measurements in the visible range from the Meteosat First and Second Generation Satellites (Posselt et al. 2012; Posselt et al. 2014). They operated from 1983 to 2015, with best quality from 1994 on (Posselt et al. 2014). The satellite data are provided on a grid of $0.05^{\circ}$ horizontal resolution (approximately $5 \mathrm{~km}$ ). Daily mean and maximum radiation were calculated from hourly mean values retrieved for the analysis period (1983-2010) in February 2017. In order to combine these gridded data with the station data, the closest grid box from the satellite data to each of the 1370 stations was considered.

\section{Model data}

Regional climate model (RCM) simulations from the Coordinated Regional Downscaling Experiment (CORDEX, Giorgi et al. (2009); Jones et al. (2011); Jacob et al. (2014); Kotlarski et al. (2014)) initiative are considered to derive climate change projections of heat exposure. These simulations represent state-of-the-art RCM scenarios (Gutowski Jr. et al. 2016; Giorgi 2019; Jacob et al. 2020) and are accessible via the Earth System Grid Federation (ESGF, https://esgf.llnl. gov/).

In this work, we use 84 simulations (GCM-RCM chains) in total performed by $11 \mathrm{RCMs}$ driven by 10 different global climate models (GCMs), at two horizontal resolutions $\left(0.11^{\circ}\right.$ and $0.44^{\circ}$, approx. 12 and $50 \mathrm{~km}$ ) and assuming three Representative Concentration Pathways (RCP2.6, RCP4.5 and RCP8.5). Historical runs for the period 1981-2005 and future projections until 2099 were considered here. Since we use the reference period 1981-2010, the years 2006-2010 from the projection runs were merged with the historical runs. Most of the simulations were extracted from the ESGF in
May 2017, and additional EURO-CORDEX-compliant simulations from ETH Zurich were also included in the analysis (Sørland et al. 2018). The reader is referred to Table S2 for a summary of the simulations used.

\section{Bias correction}

Despite their continuous improvement, RCMs are prone to systematic biases and their resolution is still too coarse for use in many sectoral climate change impact applications (Christensen et al. 2008). A common approach to account for systematic biases and to further downscale RCM results is to use distribution-based statistical transfer relations that adjust/correct systematic model biases and that might also include a downscaling component (see, e.g. Déqué (2007); Piani et al. (2010)). Among the available bias correction methods, we use empirical quantile mapping (QM) that consists of matching the simulated and observed distributions by establishing a quantile-dependent correction function, between the observed and simulated quantiles (Panofsky and Brier 1968). QM is nowadays a well-established method and was used to produce localized climate information from national climate change scenarios, e.g. in Switzerland (CH2018 2018) and Austria (Formayer et al. 2015). The implicit assumption of QM is that a climate model can sufficiently project ranked categories of the variable of interest, i.e. quantiles, but not its actual values (Déqué 2007). Here we use the implementation from Rajczak et al. (2016), where the 99 empirical percentiles of daily data are corrected and linear interpolation is used for the values between two percentiles. Constant extrapolation is applied for values outside the calibration range, i.e. the correction function of the last (first) percentile is applied to all the values above (below) it. The calibration is carried out independently for each day of the year with a moving window of 91 days, considering the full period 1981-2010, for the closest grid box from the RCMs to each of the 1370 stations. The correction functions are then applied to the historical period (1981-2010) and the future period (2070-2099) or transiently for 1981-2099 (Fig. 1). 
Each of the input parameters of the WBGT (daily maximum temperature and solar radiation and daily mean dew point and wind speed) is corrected independently prior to the index calculation. Wilcke et al. (2013) showed that univariate bias correction is able to retain the temporal structure and the inter-variable relationships of the uncorrected data. Different to multivariate bias correction methods (Vrac and Friederichs 2015; Cannon 2016), univariate techniques are less complex and easier to interpret and the parameter estimates of the transfer functions are consequently more robust. The correction of the individual variables prior to the calculation of a multivariate index or impact model is still the common and preferred approach to downscale climate indices (Teutschbein and Seibert 2012; Casanueva et al. 2018), even though it assumes statistical independence of the variables.
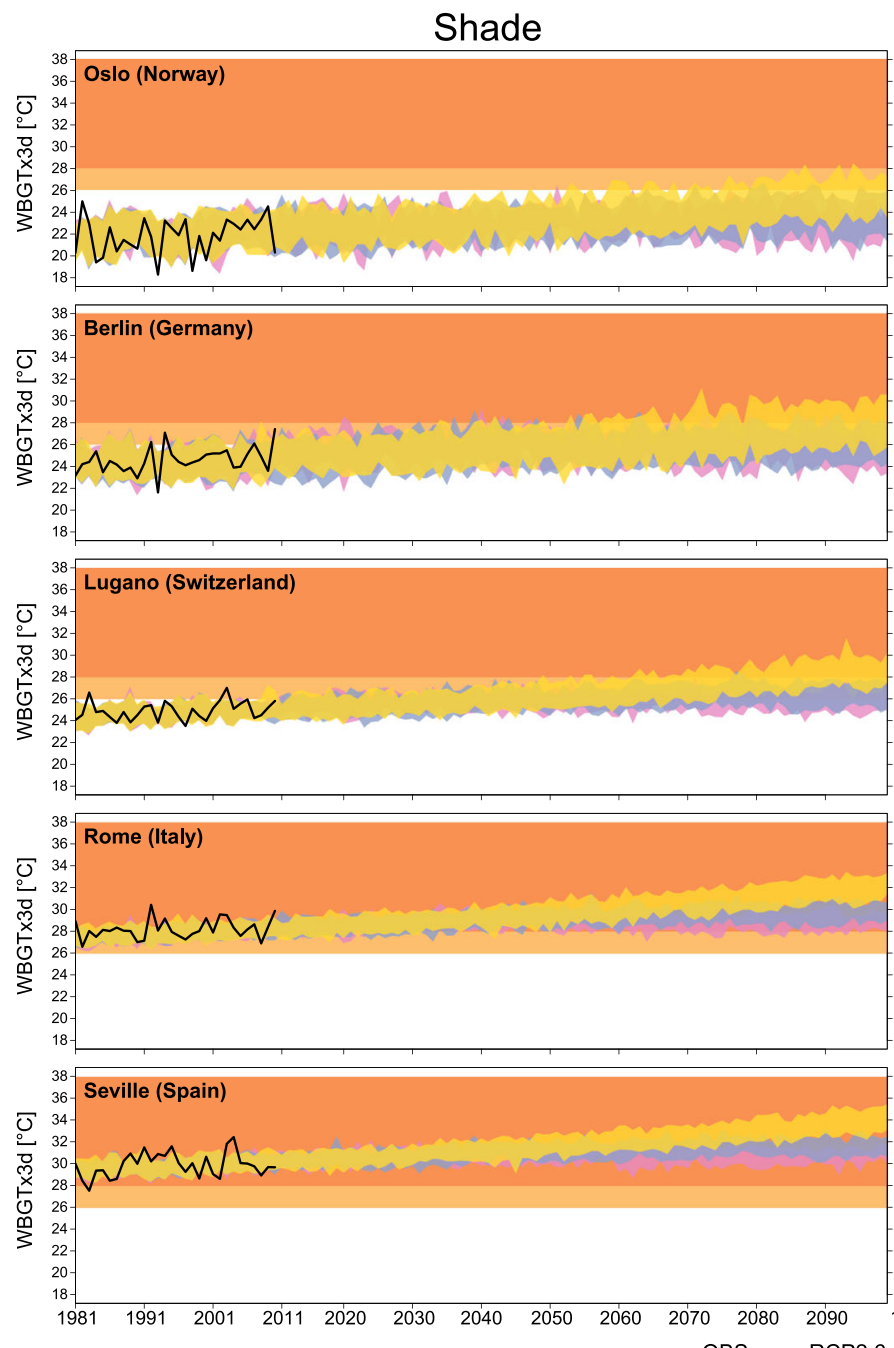

Fig. 1 Transient climate change projections of heat exposure at selected European stations. Summer maximum of moving 3-day average WBGT (WBGTx3d, left column: shade, right column: sun) for five stations as derived from observations (black) and climate change projections (three color shadings representing three RCPs; historical runs expand from 1981
The EURO-CORDEX RCMs do not provide daily maximum solar radiation, and its approximation from the available variables in the model is not straightforward. To circumvent this problem, we bias-correct daily mean solar radiation from the RCMs against daily maximum observed solar radiation. By doing this, the distribution of the mean solar radiation of the models is mapped onto the distribution of the maximum observed counterpart. Thus, the correction function is not a pure bias correction, but also translates daily mean solar radiation into daily maximum solar radiation. The suitability of this approach was tested with the SMN data (Fig. S3). Although results show an underestimation of the daily variability in the quantile mapped maximum solar radiation with respect to the observed counterpart, the effect on the WBGT is small, probably because solar radiation does not play a major role in the heat exposure index (compared to temperature and
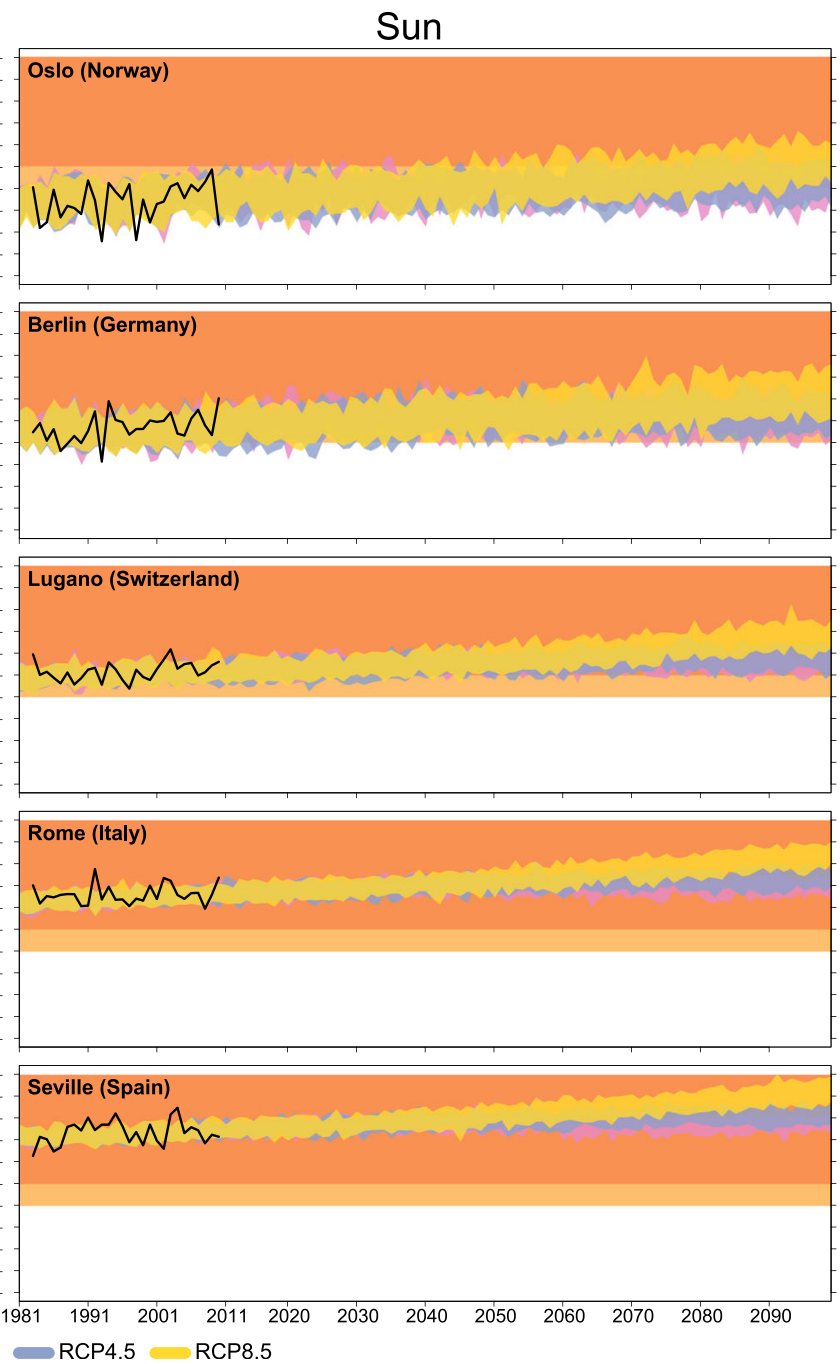

to 2005). For each RCP, the shading indicates the $80 \%$ of the model range (10th to 90th percentile). The two orange shadings in the background represent relevant WBGT thresholds (see 'Wet bulb globe temperature and derived indices') 
humidity, Fig. S4), and $\mathrm{WBGT}_{\text {sun }}$ can be fairly well reproduced.

\section{Evaluation of the bias correction}

One of the potential limitations of QM is that the inter-variable dependencies may be modified (Ehret et al. 2012; Vrac and Friederichs 2015) since it is a univariate bias correction method and does not explicitly correct for RCM biases in the physical, temporal or spatial relationships among variables. Therefore, it is crucial to verify if the WBGT calculated with the bias-corrected input variables agrees with the observed counterpart.

Figure $\mathrm{S} 5$ shows the $Q-Q$ plots of the observed vs. simulated WBGT (only summer days) for shaded and sunny conditions, for the raw (black) and bias-corrected data (blue) for five representative stations in Europe. They are representative in the sense that they cover different climates and a north-to-south gradient along the continent. Moreover, they are important European cities, with many inhabitants, which might be suffering from an increase of environmental heat exposure in the future. It is shown that after the independent correction of the input variables, the heat indices agree very well with the observations (i.e. the blue dots lie approximately on the diagonal). Thus, the inter-variable relationships are obviously retained after the correction of the individual parameters (Wilcke et al. 2013). Note that results may be less accurate in a cross-validation framework, although our approach can be considered independent since the evaluated aspect (here: multivariate consistency) is not directly tackled by QM.

\section{Results}

\section{Future increase in summer maximum heat exposure}

Previous works have shown that hot temperatures (on single days) increase faster with global warming than average temperatures (Schär et al. 2004; Fischer and Schär 2009; Cattiaux et al. 2015); thus, we first focus on the most extreme case of summer maximum WBGT. Our results show that, overall, environmental heat exposure is projected to increase in the course of the twenty-first century in Europe. For an illustrative set of European cities (Fig. 1), summer maximum WBGT (WBGTx3d, i.e. maximum of moving 3-day average WBGT; see Table 1) observed during the past 30 years ranged from $22{ }^{\circ} \mathrm{C}$ in Oslo to $30{ }^{\circ} \mathrm{C}$ in Seville for shaded conditions. Due to the effect of solar radiation, WBGT in the sun is systematically higher than WBGT in the shade, with differences of around $2-3{ }^{\circ} \mathrm{C}$ or even more for the Mediterranean stations. Until 2050, heat exposure is projected to increase similarly for all RCPs considered, while after 2050, the changes according to the three RCPs show distinct behaviour, especially for the more southerly locations. At the five illustrative stations and especially for RCP8.5, heat exposure might reach far beyond the observed range with summer maximum WBGT up to $26{ }^{\circ} \mathrm{C}$ in Oslo and $34{ }^{\circ} \mathrm{C}$ in Seville in the shade. As for the observational period, projected WGBT values in the sun are systematically higher by $2-3{ }^{\circ} \mathrm{C}$. Model uncertainty together with interannual variability (shaded range) is larger at the northern stations $\left(4-5{ }^{\circ} \mathrm{C}\right)$ and smaller for the southern locations $\left(2-3{ }^{\circ} \mathrm{C}\right)$. The uncertainty range increases in the course of the century for all of the stations and all RCPs. At Northern and Central European stations, the selected thresholds for moderate and high heat risk (orange-shaded areas in Fig. 1) are occasionally reached in the present but those conditions will occur much more often in the future.

Single-day summer maximum WBGT (WBGTx1d) increases by $1-4{ }^{\circ} \mathrm{C}$ by the end of the twenty-first century with respect to the historical reference period depending on the specific station and on the emission scenario (Fig. S6). Changes of WBGTx1d are more uniform across the continent than air temperature changes which are higher in Southern Europe than in the north (Jacob et al. 2014; Kröner et al. 2017). This might be due to the projected decrease in relative humidity in the Mediterranean region (Ruosteenoja and Räisänen 2013), which counterbalances the strong temperature increase and hence results in a smaller WBGT change (note the effect of increasing temperature and decreasing dew point temperature on WBGT in Fig. S4), in agreement with Brouillet and Joussaume (2019). In general, future environmental heat exposure is enhanced in those regions where it is already a problem in today's climate, resulting in a clear northsouth heat exposure gradient (Fig. 2). For instance, in Southern Europe, WBGTx1d in the shade reaches 27 $29{ }^{\circ} \mathrm{C}$ in present-day climate and might amount to 28 $29{ }^{\circ} \mathrm{C}, 28-30{ }^{\circ} \mathrm{C}$ and $30-32{ }^{\circ} \mathrm{C}$ for the three RCPs, respectively. Accordingly, WBGTx1d in the sun is projected to rise from $30-32{ }^{\circ} \mathrm{C}$ to $31-33{ }^{\circ} \mathrm{C}, 32-34{ }^{\circ} \mathrm{C}$ and 34 $36{ }^{\circ} \mathrm{C}$, respectively. In Central Europe, where nowadays WBGTx1d ranges between 24 and $26{ }^{\circ} \mathrm{C}$ (in the shade) and 27 and $29{ }^{\circ} \mathrm{C}$ (in the sun), it may reach up to $30^{\circ} \mathrm{C}$ and $32{ }^{\circ} \mathrm{C}$ under the strongest emission scenario (RCP8.5) in many locations.

The climate change signal for summer mean WBGT (WBGTmean) is very similar to that for the summer maximum (WBGTx1d, see Fig. S7), unlike the amplification found in temperature extremes compared to mean temperature changes (Fischer and Schär 2010). A possible reason for this could be the role of humidity (dew point temperature) which contributes to WBGT and, thereby, modulates the pure temperature signal. Dew point temperature shows very similar changes of summer mean and maximum values (Fig. S7, blue points). 

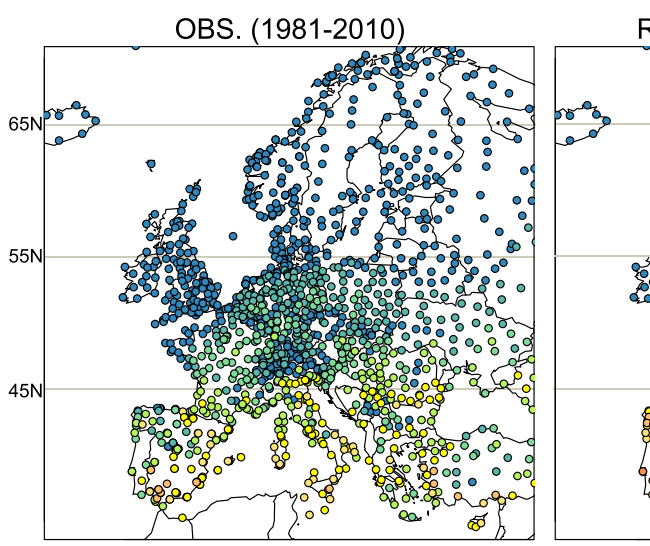

Fig. 2 Observed and projected summer maximum heat exposure. Observed (left) and multi-model projected (middle) summer maximum heat exposure (WBGTx1d) in the shade. Projections show the ensemble median (over 39 model chains) for the strongest emission scenario for 2070-2099. The highest values are plotted on top of lower ones to

\section{High heat exposure to become more frequent in the future}

The described increase of summer mean and maximum WGBT is associated with more frequent situations with high heat risk (Fig. 3). In the shade, the number of summer days with high heat risk (WBGTg28) currently reaches up to 20 days on average in a few locations in Spain, Italy, Greece and Cyprus (Fig. 3, left), whereas in the sun, the area with such conditions spans over Southern Europe and reaches 3050 days in some Mediterranean locations. Frequencies of high heat risk for both shaded and sunny conditions are projected to increase by $5-15,15-30$ and $30-50$ days per year in the Mediterranean region by the end of the century with respect to today's climate for the three RCPs, respectively (Fig. S8). Hence, on average, there will be 5-15, 10-40 and 20-70 days with high heat risk per summer season for shaded and 20-50, 30-60 and 50-80 for sunny conditions for the three RCPs in the Mediterranean area (Fig. 3, middle and right).

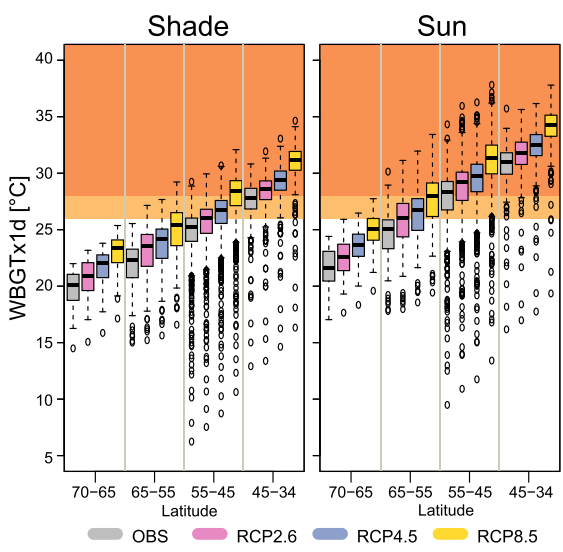

highlight the most affected locations. Boxplots (right) summarize the results for the three RCPs $(2.6,4.5$ and 8.5) and two WBGT implementations (shade and sun) for stations lying in four latitudinal belts (see maps). The two orange shadings in the background represent critical WBGT thresholds (see 'Wet bulb globe temperature and derived indices')

In some Southern European locations, workers might suffer high heat risk at the end of this century for almost the entire summer in sunny conditions (values close to $100 \%$ ) and more than half of the summer days under shade conditions (Table 2). The comparison between the frequencies of WBGT above $26^{\circ} \mathrm{C}$ and $28^{\circ} \mathrm{C}$ (see 'Wet bulb globe temperature and derived indices') partly samples the uncertainty due the acclimatization state of the worker for the specific case under moderate work intensity (NIOSH 2016; ISO 2017). Although the frequency of heat risk is lower for acclimatized workers (Table 2, right columns: WBGTg28), future changes with respect to present-day climate might be up to 2 times larger than for unacclimatized workers (WBGTg26) in Mediterranean locations for WBGT in the sun. In these locations, the frequency of high heat risk is substantial even for the low-emission scenario. While high risk in shaded conditions is confined to the Mediterranean area, it extends northwards for WBGT in the sun, affecting the entire continent except Scandinavia and the British Isles by 2100 (cf. Fig. S8). High
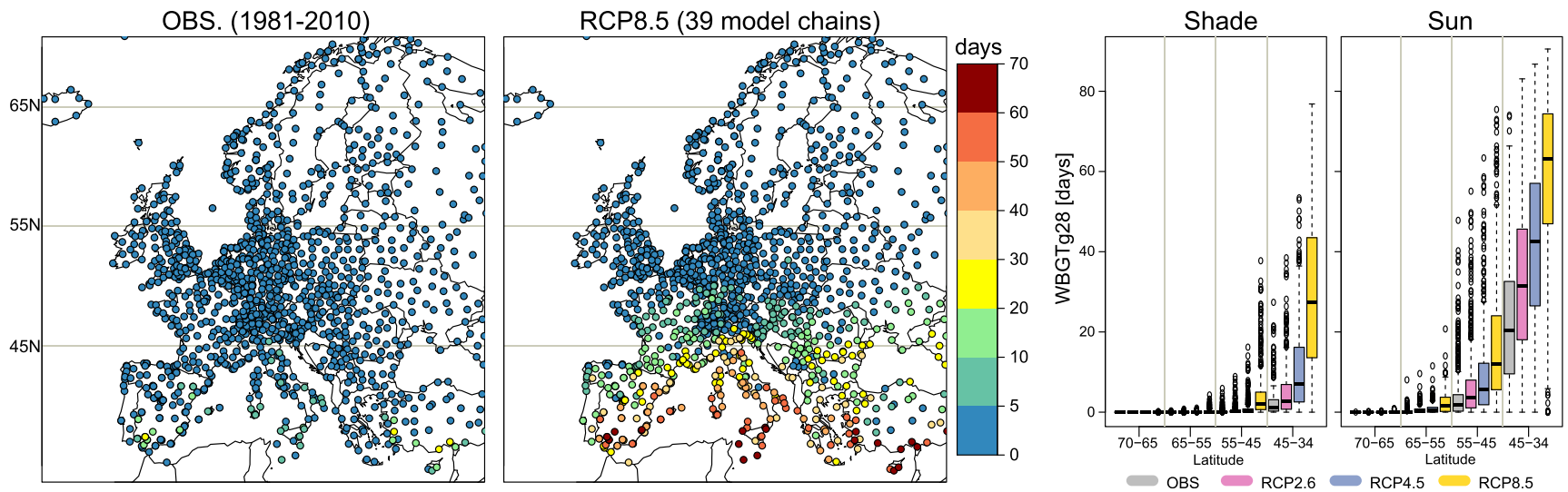

Fig. 3 Observed and projected number of days with high heat risk. As Fig. 2, but for the frequency of days with high heat risk (WBGTg28). The two maps refer to shaded conditions 


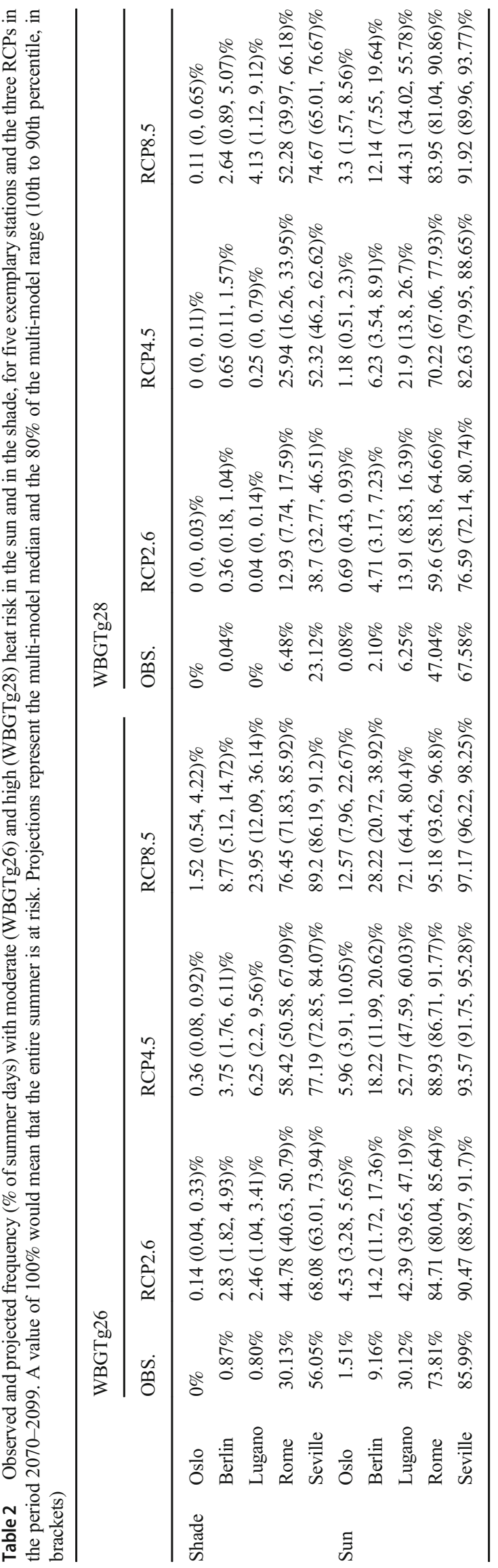

heat risk (WBGTg28) in the sun is projected to occur during up to $10 \%$ of summer days in many locations in Central Europe for the low- and medium-emission scenarios and even on $20-30 \%$ of summer days for RCP8.5 (Fig. 3 and Table 2). Thus, many workers in Europe need to adapt to a future with more frequent heat situations, even when performing moderate work.

\section{Model uncertainty in the climate change signal}

Uncertainties in climate projections often represent a challenge for climate change communication and its interpretation by stakeholders. Climate indices, such as heat indices, offer the possibility to describe the climate in a more approachable way. The joint assessment of uncertainties using multivariate indices can potentially increase or compensate model uncertainties depending on the case (Fischer and Knutti 2013). The uncertainty in the climate change signal of WBGT would be modulated by the model uncertainty of all input variables (air and dew point temperature, wind speed and radiation) and the relationships among them (Fischer and Knutti 2013). Here, the ratio between the multi-model mean change (signal) and standard deviation of the multi-model changes (uncertainty) is used as an indicator to compare the model agreement relative to the projected change for summer maximum WBGT (WGBTx1d) in the shade and the input variables (Fig. 4). This ratio is large for most of the stations in the Mediterranean region and Central and Southeast Europe, especially for RCP8.5 for which larger signals are projected (Fig. 4i). That means that the uncertainty is small compared to the signal. Signal-to-noise ratios are larger for WGBT and dew point temperature than for maximum temperature over many regions, implying that the incorporation of dew point temperature increases the robustness (Fig. 4). This result is consistent with previous findings (Fischer and Knutti 2013) and highlights the potential source of predictability provided by relative humidity, which has been found in climate change assessments (Scoccimarro et al. 2017) and seasonal forecasts (Bedia et al. 2018). The north-south pattern in the signal-tonoise ratios of WBGT in the shade (Fig. 4g-i) may explain the differences in the model uncertainty by the end of the twenty-first century in Fig. 1, since in Northern Europe there is larger uncertainty for air temperature projections than in the south.

More robust results for WBGT than air temperature also hold for RCP2.6 although with smaller signal-to-noise ratios, due to the smaller signals, and large uncertainties in Northern Europe where two simulations project a much larger temperature increase than the RCP2.6 ensemble mean.

Other sources of uncertainty beyond model uncertainty are discussed in the Supplementary Material (Annex C). 


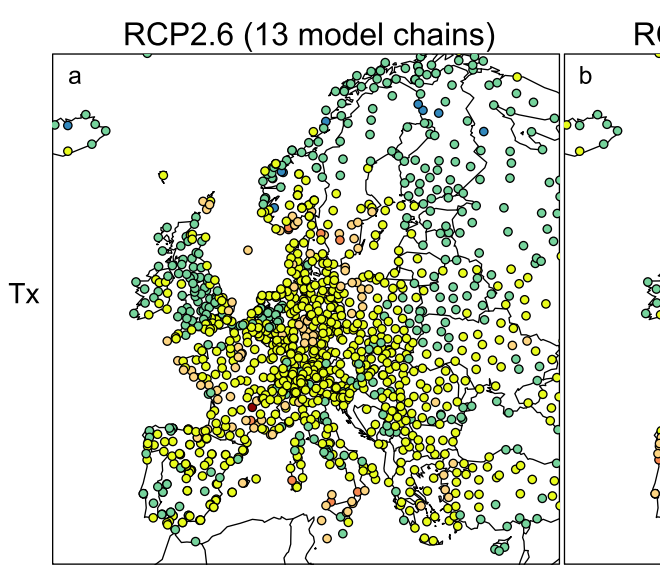

RCP4.5 (32 model chains)

RCP8.5 (39 model chains)
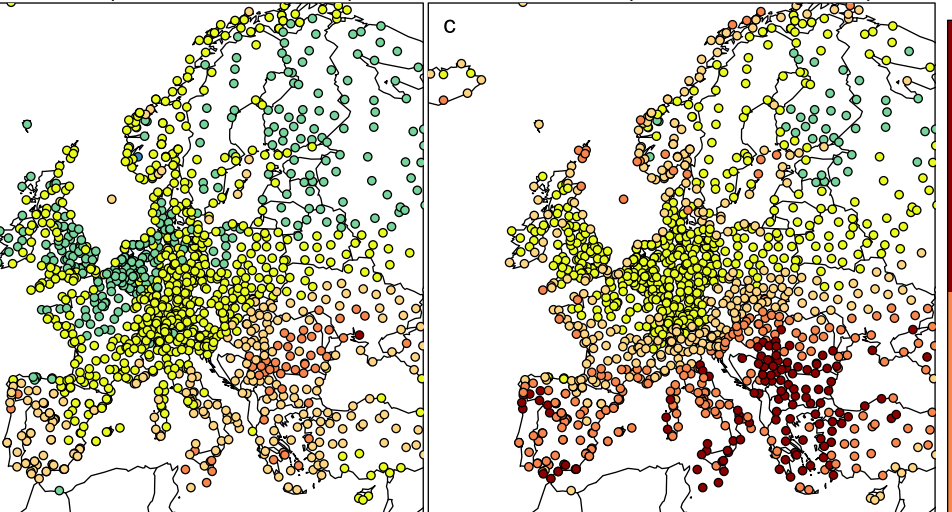

5

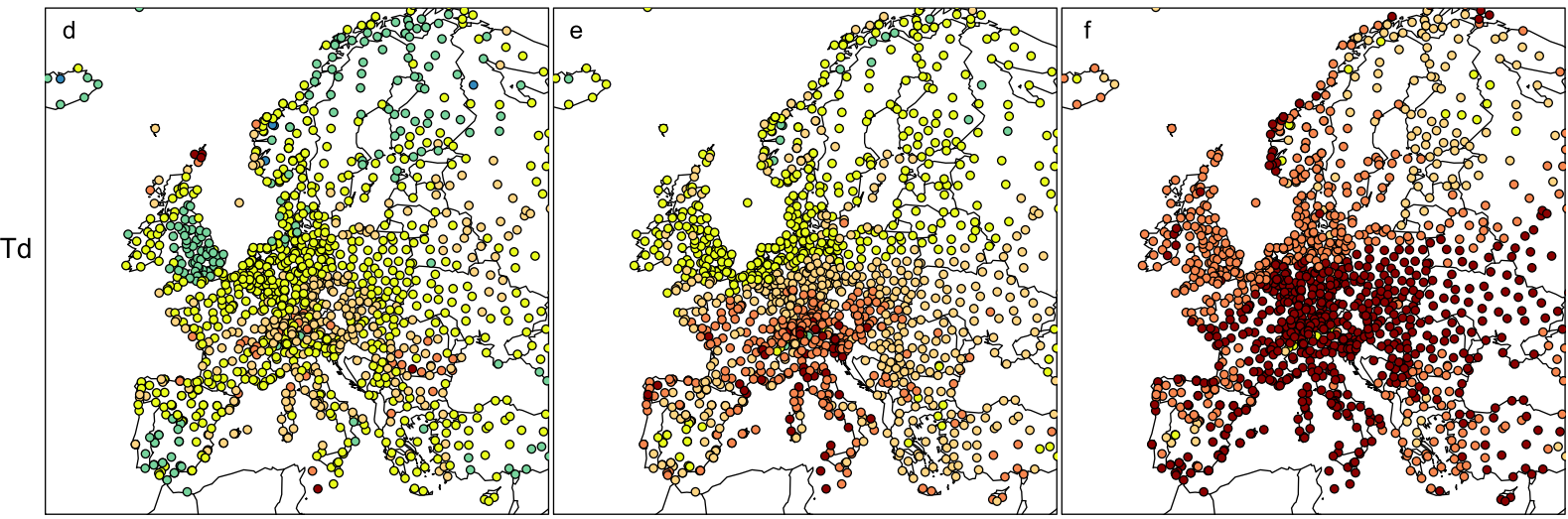

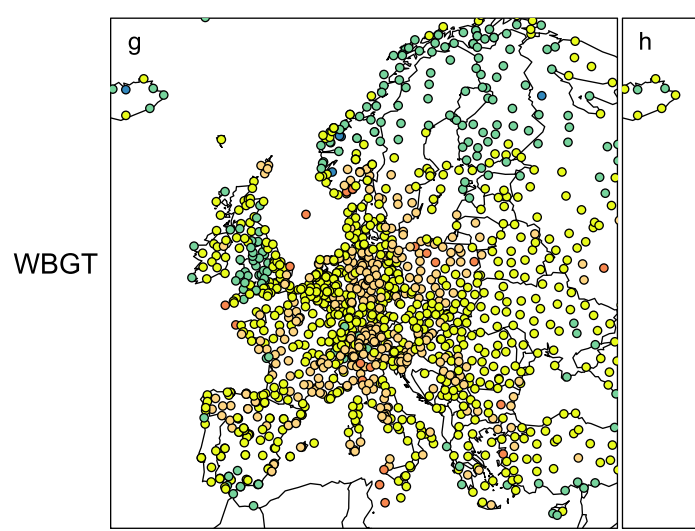

Fig. 4 Multi-model ensemble signal vs. spread (i.e. signal-to-noise ratio). Ratio of the multi-model ensemble mean change and multi-model spread (represented by the standard deviation) of summer maximum values of

\section{Productivity losses due to heat exposure applying ISO recommendations}

The workers' natural response to protect themselves against the risk of heat-related illnesses is to slow down work intensity and/or limit working hours, thus minimizing body heat production and reducing heat exposure, respectively (Ioannou et al. 2017). As a consequence of these strategies, labour productivity and economic output are reduced (Kjellstrom et al. 2009a; Kjellstrom, et al., 2009b). Staying below certain daily maximum temperature (Tx, a-c), dew point temperature $(\mathrm{Td}, \mathbf{d}-\mathbf{f})$ and heat exposure (WBGT in the shade, $\mathbf{g}-\mathbf{i}$ ), for the three RCPs during the period 2070-2099

exposure limits (e.g. ambient temperature below $35{ }^{\circ} \mathrm{C}$ (Kjellstrom et al. 2009b) and core body temperature below $38{ }^{\circ} \mathrm{C}$ (Kjellstrom et al. 2009a)) reduces the risk of heatrelated illness, but does not preclude the possibility of other adverse effects such as a loss of productivity. For that purpose, specific epidemiological studies (Wyndham 1969; Sahu et al. 2013) have been used to estimate relationships between exposure (heat level) and response (productivity) (Kjellstrom et al. 2018). For moderate work intensity (300-350 W), when WBGT is above $31{ }^{\circ} \mathrm{C}$, the hourly work capacity is reduced 
by $25 \%$ for an average worker according to these epidemiological studies (Kjellstrom et al. 2018). International standards (ISO 1989) would be more restrictive than that $\left(70 \%\right.$ of losses for WBGT above $31{ }^{\circ} \mathrm{C}$, Kjellstrom et al. 2018), because they are based on heat levels that protect most of the workforce.

We quantify the productivity losses (reduction in available work time) that would occur if the international standard recommendations are enforced (ISO 1989, see 'Wet bulb globe temperature and derived indices'). If working people do not reduce their work as much, the losses would be less but at the expense of other effects on workers' well-being (Flouris et al. 2018). These ISO recommendations apply to acclimatized workers; thus, they might be more appropriate for Southern European cities. In present-day climate, there are only few locations in the Mediterranean area where up to $20 \%$ of summer working hours are lost under sunny conditions (Fig. 5, left). By the end of the twenty-first century, under RCP8.5, Southern Europe will experience a widespread loss of working hours by at least $15 \%$, reaching more than $50 \%$ in some locations in Spain, Italy, Greece and Cyprus (Fig. 5, middle). The different estimates of productivity losses vary nonlinearly with the three emission scenarios, and substantial differences are projected between RCP4.5 and RCP8.5 for specific hot spots such as Rome and Seville (Fig. 5, right).

\section{Discussion and conclusions}

Changes in environmental heat exposure due to climate change are highly relevant to stakeholders and policy makers in order to respond to possible impacts on the main European industries. At the end of the twenty-first century, many European workers will very likely be affected by heat stress, not only due to the increase of heat exposure but also because such situations will become more frequent in large areas of the continent. This will affect not only the south of the continent but — especially for workers active in the sun - also regions in Central and Northern Europe, where heat exposure has a smaller effect in present-day climate. Even if stronger global mitigation actions are implemented (RCP2.6), high heat risk is found for large parts of Southern Europe during the twenty-first century, underlining the need for reconsidering international working regulations for European industries to reduce heat exposure. A direct consequence of environmental heat is the loss in labour productivity especially for sunny conditions, which can result in a reduction of $15-60 \%$ of the working hours in the Mediterranean area under the strongest emission scenario by the end of the twenty-first century. Model uncertainty may be large, but the current study shows a strong agreement among climate models in terms of an increased heat risk. Furthermore, climate change projections of summer maximum heat exposure are more robust than those for maximum air temperature, mainly due to the higher model agreement in dew point temperature. We focus on the effects of summer heat exposure on labour productivity, but a broader picture would consider non-linear effects (Burke, et al., 2015), e.g. future warming might increase outside labour productivity during the winter months in northern Europe, thus compensating the loss in summer due to high temperatures.

In light of the results presented here, mitigation and adaptation measures should be taken to prevent productivity losses in the course of the twenty-first century. Some protective strategies to alleviate heat exposure might be heat wave monitoring and warning, a reduction of sources of heat in workplaces, a reduction of physical work intensity, personal protection through movable personal microclimate cooling and sophisticated technical developments in clothing based on cooling
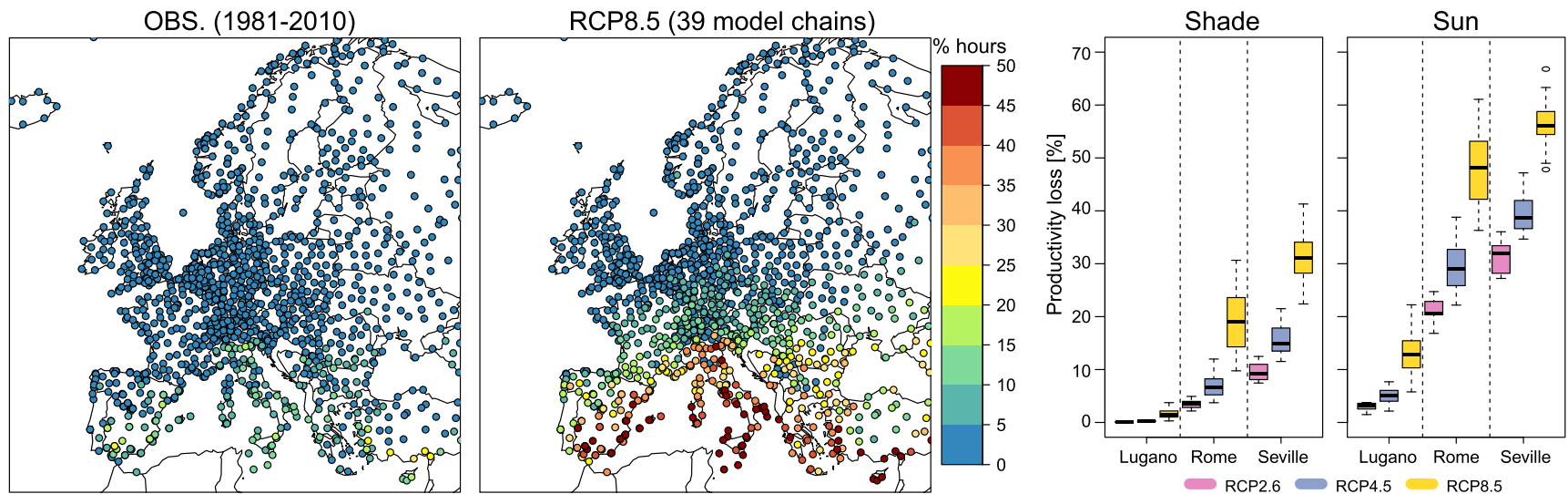

Fig. 5 Productivity loss due to environmental heat exposure. Observed (left) and projected (middle) percentage of summer working hours lost due to heat exposure under sunny conditions. Projections show the multimodel ensemble median (over 39 model chains) for the strongest emission scenario RCP8.5 and the period 2070-2099. Boxplots (right) summarize the projected percentage of working hours lost by the end of the century for the two WBGT implementations (shade and sun) and three selected European stations. Each boxplot represents the multi-model uncertainty range for each RCP and location. To obtain the percentage of summer working hours lost due to heat exposure, we approximate hourly values of WBGT by combining daily mean and maximum values of WBGT (Kjellstrom, et al., 2018) and apply the exposure-response relationship from ISO (1989) (see 'Wet bulb globe temperature and derived indices') 
with ventilation and phase change materials that absorb or release latent heat when they change phases (Gao et al. 2018). Since reducing heat exposure by the workers (i.e. limit working hours, increase pauses) derives in productivity losses, there might be, however, a tradeoff between reducing heat exposure and preventing productivity losses that needs to be assessed case by case. In order to cope with this situation, specific solutions need to be applied for each case, including feasible, sustainable and effective solutions (Morris et al. 2020).

The analysed RCM simulations do not include a dedicated module for urban climates, and the implemented land use is static. Moreover, meteorological stations as those used here for the bias correction are usually located outside the cities, such as at airports or in rural environments. Thus, the urbanization effect is underestimated and not fully accounted for in our analysis. Further research is needed to assess the urban heat island effect and to quantify future heat exposure in urban areas on a European scale. The urban heat island effect is, for instance, associated with warmer nights in urban compared to rural areas (Oleson et al. 2011; Parlow et al. 2014). In a warmer climate, a higher frequency of high-heat-stress nights and tropical nights in urban compared to rural sites is projected (Fischer et al. 2012; Burgstall 2019 and references therein). This is highly relevant since people in cities might not recover from the daytime heat and might subsequently not be able to handle any extreme heat the following day (Perkins, 2015). So, the results presented in this study should be regarded as a lower bound of future heat risk in urban areas.

Many opportunities arise based on this work. The climate change projections of environmental heat exposure could be combined with demographic data and economic models in order to quantify economic losses due to heat (as foreseen in the HEAT-SHIELD project; see www.heat-shield.eu). At shorter time scales, a heat-warning system has been developed in order to allow stakeholders timely and precise prevention strategies and better planning of the work activities up to four weeks in advance (see http://heatshield.zonalab.it). Accordingly, the development and dissemination of heathealth planning and warning systems is now among the priorities of the World Meteorological Organization (WMO) and the World Health Organization (WHO). All these examples are certainly a good test bed for developing effective climate services in the context of extreme heat.

\footnotetext{
Acknowledgements The authors are grateful to the observational data providers: ECA\&D project, the National Centers for Environmental Information, NESDIS, NOAA, U.S. Department of Commerce and the satellite-based data from EUMETSAT's Satellite Application Facility on Climate Monitoring (CM SAF). We acknowledge the World Climate Research Programme's Working Group on Regional Climate, and the Working Group on Coupled Modelling, former coordinating body of CORDEX and responsible panel for CMIP5. We also thank the climate modelling groups for producing and making available their model output,
}

the Earth System Grid Federation infrastructure, an international effort led by the U.S. Department of Energy's Program for Climate Model Diagnosis and Intercomparison, the European Network for Earth System Modelling and other partners in the Global Organisation for Earth System Science Portals (GO-ESSP). We thank Dr. Silje Soerland and Dr. Daniel Lüthi from ETH Zurich for producing the EUROCORDEX-compliant simulations, Curdin Spirig and Dr. Jan Rajczak (ETH Zurich) for pre-processing the simulation data and Dr. Anke Duguay-Tetzlaff from MeteoSwiss and Dr. Jörg Trentmann from DWD for providing the satellite data.

The authors are also grateful to Dr. Jan Rajczak (ETH Zurich) for providing an earlier version of the quantile mapping code, Dr. James C. Liljegren (Argonne National Laboratory, Illinois) for making the wet bulb globe temperature code for sun conditions available, Dr. Erich Fischer (ETH Zurich) for inspiring the analysis under Fig. 4, and Dr. Christoph Spirig and Dr. Jonas Bhend (MeteoSwiss), both responsible for the heatwarning system, for their input to establish a common approach. We also thank our HEAT-SHIELD colleagues (www.heat-shield.eu) and the CH2018 group (www.ch2018.ch) for technical support and scientific discussions.

Financial support for this work is provided by the HEAT-SHIELD Project (European Commission HORIZON 2020, research and innovation programme under the grant agreement 668786). The authors wish to thank the Swiss National Supercomputing Centre (CSCS) for providing the technical infrastructure.

Finally, the authors are also grateful to the editor and two anonymous reviewers who helped to improve the original manuscript.

Open Access This article is licensed under a Creative Commons Attribution 4.0 International License, which permits use, sharing, adaptation, distribution and reproduction in any medium or format, as long as you give appropriate credit to the original author(s) and the source, provide a link to the Creative Commons licence, and indicate if changes were made. The images or other third party material in this article are included in the article's Creative Commons licence, unless indicated otherwise in a credit line to the material. If material is not included in the article's Creative Commons licence and your intended use is not permitted by statutory regulation or exceeds the permitted use, you will need to obtain permission directly from the copyright holder. To view a copy of this licence, visit http://creativecommons.org/licenses/by/4.0/.

\section{References}

American Conference of Governmental Industrial Hygienists (ACGIH) (2016) Heat stress and strain: documentation of TLVs and BELs. www.acgih.org. Accessed May 2019

Barriopedro D, Fischer EM, Luterbacher J, Trigo RM, García-Herrera R (2011) The hot summer of 2010: redrawing the temperature record map of Europe. Science 32:220-224. https://doi.org/10.1126/ science. 1201224

Bedia J, Golding N, Casanueva A, Iturbide M,Buontempo C, Gutiérrez JM (2018) Seasonal predictions of fire weather index: paving the way for their operational applicability in Mediterranean Europe. Clim Serv 9:101-110. https://doi.org/10.1016/j.cliser.2017.04.001

Bernard TE, Pourmoghani M (1999) Prediction of workplace wet bulb global temperature. Appl Occup Environ Hyg 14:126-134. https:// doi.org/10.1080/104732299303296

Bilbao J, Miguel AH, Kambezidis HD (2002) Air temperature model evaluation in the North Mediterranean Belt Area. J Appl Meteorol 41:872-884. https://doi.org/10.1175/1520-0450(2002)041<0872: ATMEIT>2.0.CO;2

Brouillet A, Joussaume S (2019) Investigating the role of the relative humidity in the co-occurrence of temperature and heat stress 
extremes in CMIP5 projections. Geophys Res Lett 41:435-443. https://doi.org/10.1029/2019GL084156

Burgstall A (2019) Representing the urban heat island effect in future climates. MSc Thesis Univ Augsburg. Available at https://www. meteoschweiz.admin.ch/home/service-und-publikationen/ publikationen.subpage.html/de/data/publications/2020/2/ representing-the-urban-heat-island-effect-in-future-climates.hmtl. Accessed Feb 2020

Burgstall A, Casanueva A, Kotlarski S, Schwierz C (2019) Heat warnings in Switzerland: reassessing the choice of the current heat stress index. Int J Environ Res Public Health 16:2684. https://doi.org/10. 3390/ijerph16152684

Burke M, Hsiang S, Miguel E (2015) Global non-linear effect of temperature on economic production. Nature 527:235-239. https://doi.org/ 10.1038 /nature 15725

Cannon AJ (2016) Multivariate bias correction of climate model output: matching marginal distributions and intervariable dependence structure. J Clim 29:7045-7064. https://doi.org/10.1175/JCLI-D-150679.1

Casanueva A, Bedia J, Herrera S, Fernández J, Gutiérrez JM (2018) Direct and component-wise bias correction of multi-variate climate indices: the percentile adjustment function diagnostic tool. Clim Chang 147:411-425. https://doi.org/10.1007/s10584-018-2167-5

Cattiaux J, Douville H, Schoetter R, Parey S, Yiou P (2015) Projected increase in diurnal and interdiurnal variations of European summer temperatures. Geophys Res Lett 42:899-907. https://doi.org/10. 1002/2014GL062531

CH2018, 2018 CH2018 - climate scenarios for Switzerland, Technical Report. National Centre for Climate Services, Zurich

Christensen JH, Boberg F, Christensen OB, Lucas-Picher P (2008) On the need for bias correction of regional climate change projections of temperature and precipitation. Geophys Res Lett 10(35):L20709. https://doi.org/10.1029/2008GL035694

Coccolo S, Kämpf J, Scartezzini J-L, Pearlmutter D (2016) Outdoor human comfort and thermal stress: a comprehensive review on models and standards. Urban Clim 18:33-57. https://doi.org/10.1016/j. uclim.2016.08.004

Coffel ED, Horton RM, Sherbinin A (2018) Temperature and humidity based projections of a rapid rise in global heat stress exposure during the 21st century. Environ Res Lett 13:014001. https://doi.org/10. 1088/1748-9326/aaa00e

Déqué M (2007) Frequency of precipitation and temperature extremes over France in an anthropogenic scenario: model results and statistical correction according to observed values. Glob Planet Chang 5(57):16-26. https://doi.org/10.1016/j.gloplacha.2006.11.030

Dunne JP, Stouffer RJ, John JG (2013) Reductions in labour capacity from heat stress under climate warming. Nat Clim Chang 3:563566. https://doi.org/10.1038/nclimate1827

Ehret U, Zehe E, Wulfmeyer V, Warrach-Sagi K, Liebert J (2012) HESS opinions Should we apply bias correction to global and regional climate model data? Hydrol Earth Syst Sci 9(16):3391-3404. https://doi.org/10.5194/hess-16-3391-2012

Fischer EM, Oleson KW, Lawrence DM (2012) Contrasting urban and rural heat stress responses to climate change. Geophys Res Lett 39. https://doi.org/10.1029/2011GL050576

Fischer EM, Schär C (2009) Future changes in daily summer temperature variability: driving processes and role for temperature extremes. Clim Dyn 33. https://doi.org/10.1007/s00382-008-0473-8

Fischer EM, Schär C (2010) Consistent geographical patterns of changes in high-impact European heatwaves. Nat Geosci 3:398-403. https:// doi.org/10.1038/ngeo866

Fischer EM, Knutti R (2013) Robust projections of combined humidity and temperature extremes. Nat Clim Chang 3:126-130. https://doi. org/10.1038/nclimate1682

Flouris AD, Dinas PC, Ioannou LG, Nybo L, Havenith G, Kenny GP, Kjellstrom T (2018) Workers' health and productivity under occupational heat strain: a systematic review and meta-analysis. Lancet Planet Health 2:e521-e531. https://doi.org/10.1016/S25425196(18)30237-7

Formayer H, Nadeem I, Anders I (2015) Climate change scenario: from climate model ensemble to local indicators. In: Cham KW, Steininger M, König B, Bednar-Friedl L, Kranzl F, Prettenthaler (eds) Economic evaluation of climate change impacts. Development of a cross-sectoral framework and results for Springer, Austria. https://doi.org/10.1007/978-3-319-12457-5_5

Gao C, Kuklane K, Östergren PO, Kjellstrom T (2018) Occupational heat stress assessment and protective strategies in the context of climate change. Int J Biometeorol 01 3(62):59-371. https://doi.org/10.1007/ s00484-017-1352-y

Giorgi F (2019) Thirty years of regional climate modeling: Where are we and where are we going next? J Geophys Res-Atmos 124:56965723. https://doi.org/10.1029/2018JD030094

Giorgi F, Jones C, Asrar GR (2009) Addressing climate information needs at the regional level: the CORDEX framework. WMO Bull 58:175-183

Gutowski WJ Jr, Giorgi F, Timbal B, Frigon A, Jacob D, Kang HS, Raghavan K, Lee B, Lennard C, Nikulin G, O'Rourke E, Rixen M, Solman S, Stephenson T, Tangang F (2016) WCRP COordinated regional downscaling EXperiment (CORDEX): a diagnostic MIP for CMIP6. Geosci Model Dev 9:4087-4095. https:// doi.org/10.5194/gmd-9-4087-2016

Haylock MR, Hofstra N, Klein Tank AMG, Klok EJ, Jones PD, New M (2008) A European daily high-resolution gridded data set of surface temperature and precipitation for 1950-2006. J Geophys ResAtmos:113. https://doi.org/10.1029/2008JD010201

Ioannou LG, Tsoutsoubi L, Samoutis G, Bogataj LK, Kenny GP, Nybo L, Kjellstrom T, Flouris AD (2017) Time-motion analysis as a novel approach for evaluating the impact of environmental heat exposure on labor loss in agriculture workers. Temperature 4:330-340. https:// doi.org/10.1080/23328940.2017.1338210

IPCC (2013) Climate change 2013: the physical science basis. Contribution of working group I to the fifth assessment report of the intergovernmental panel on climate change. In: Stocker TF, Qin D, Plattner G-K, Tignor M, Allen SK, Boschung J, Nauels A, Xia Y, Bex V, Midgley PM (eds). Cambridge University Press, Cambridge and New York, p 1535

ISO (1989) Hot environments - estimation of the heat stress on working man, based on the WBGT-index (wet bulb globe temperature). ISO Standard 7243 ed. International 371 Standards Organization, Geneva

ISO (2017) Hot environments - Ergonomics of the thermal environment - assessment of heat stress using the WBGT (wet bulb globe temperature) index. ISO standard 7243. ed. International Standards Organization, Geneva

Jacob D, Petersen J, Eggert B, Alias A, Christensen OB, Bouwer LM, Braun A, Colette A, Déqué M, Georgievski G, Georgopoulou E, Gobiet A, Menut L, Nikulin G, Haensler A, Hempelmann N, Jones C, Keuler K, Kovats S, Kröner N, Kotlarski S, Kriegsmann A, Martin E, van Meijgaard E, Moseley C, Pfeifer S, Preuschmann S, Radermacher C, Radtke K, Rechid D, Rounsevell M, Samuelsson P, Somot S, Soussana JF, Teichmann C, Valentini R, Vautard R, Weber B, Yiou P(2014) EURO-CORDEX: new high-resolution climate change projections for European impact research. Reg Environ Chang 14:563-578. https://doi.org/10.1007/s10113-013-0499-2

Jacob D, Teichmann C, Sobolowski S, Katragkou E, Anders I, Belda M, Benestad R, Boberg F, Buonomo E, Cardoso RM, Casanueva A, Christensen OB, Christensen JH, Coppola E, De Cruz L, Davin EL, Dobler A, Domínguez M, Fealy R, Fernandez J, Gaertner MA, García-Díez M, Giorgi F, Gobiet A, Goergen K, Gómez-Navarro JJ, González Alemán JJ, Gutiérrez C, Gutiérrez JM, Güttler I, Haensler A, Halenka T, Jerez S, Jiménez-Guerrero P, Jones RG, Keuler K, Kjellström E, Knist S, Kotlarski S, Maraun D, van 
Meijgaard E, Mercogliano P, Montávez JP, Navarra A, Nikulin G, de Noblet-Ducoudré N, Panitz HJ, Pfeifer S, Piazza M, Pichelli E, Pietikäinen JP, Prein AF, Preuschmann S, Rechid D, Rockel B, Romera R, Sánchez E, Sieck K, Soares PMM, Somot S, Srnec L, Sørland SL, Termonia P, Truhetz H, Vautard R, Warrach-Sagi K, Wulfmeyer V (2020) Regional climate downscaling over Europe: perspectives from the EURO-CORDEX community. Reg Environ Change. https://doi.org/10.1007/s10113-020-01606-9

Jones C, Giorgi F, Asrar G (2011) The Coordinated Regional Downscaling Experiment: CORDEX, an international downscaling link to CMIP5. CLIVAR Exchanges 56-16(2):34-40

Junge N, Jørgensen R, Flouris AD, Nybo L (2016) Prolonged self-paced exercise in the heat - environmental factors affecting performance. Temperature 3:539-548. https://doi.org/10.1080/23328940.2016. 1216257

Kenny GP, Flouris AD (2014) Protective clothing: managing thermal stress. In: Wang F, Gao C (eds) S.1., Woodhead publishing limited, Cambridge. https://doi.org/10.1016/C2013-0-16439-2

Kjellstrom T, Holmer I, Lemke B (2009a) Workplace heat stress, health and productivity -an increasing challenge for low and middleincome countries during climate change. Global Health Action 2. https://doi.org/10.3402/gha.v2i0.2047

Kjellstrom T, Freyberg C, Lemke B, Otto M, Briggs D (2018) Estimating population heat exposure and impacts on working people in conjunction with climate change. Int J Biometeorol 01 3(62):291-306. https://doi.org/10.1007/s00484-017-1407-0

Kjellstrom T, Kovats RS, Lloyd SJ, Holt T, Tol RSJ (2009b) The direct impact of climate change on regional labour productivity. Arch Environ Occup Health 64:217-227. https://doi.org/10.1080/ 19338240903352776

Klein Tank AMG, Wijngaard JB, Können GP, Böhm R, Demarée G, Gocheva A, Mileta M, Pashiardis S, Hejkrlik L, Kern Hansen C, Heino R, Bessemoulin P, Müller Westermeier G, Tzanakou M, Szalai S, Pálsdóttir T, Fitzgerald D, Rubin S, Capaldo M, Maugeri M, Leitass A, Bukantis A, Aberfeld R, van Engelen AFV, Forland E, Mietus M, Coelho F, Mares C, Razuvaev V, Nieplova E, Cegnar T, López JA, Dahlström B, Moberg A, Kirchhofer W, Ceylan A, Pachaliuk O, Alexander LV, Petrovic P (2002) Daily dataset of 20th-century surface air temperature and precipitation series for the European climate assessment. Int J Climatol 22:1441-1453. https://doi.org/10.1002/joc. 773

Knutson TR, Ploshay JJ (2016) Detection of anthropogenic influence on a summertime heat stress index. Climatic Change, 01 9(138)25-39. https://doi.org/10.1007/s10584-016-1708-z

Koppe C, Kovats S, Jendritzky G, Menne B (2004) Heat waves: risks and responses. No. 2. World Health Organisation, Copenhagen ed. s.1. Health and Global Environmental Change Series. https://apps.who. int/iris/handle/10665/107552

Kotlarski S, Keuler K, Christensen OB, Colette A, Déqué M, Gobiet A, Goergen K, Jacob D, Lüthi D, van Meijgaard E, Nikulin G, Schär C, Teichmann C, Vautard R, Warrach-Sagi K, Wulfmeyer V (2014) Regional climate modeling on European scales: a joint standard evaluation of the EURO-CORDEX RCM ensemble. Geosci Model Dev 7:1297-1333. https://doi.org/10.5194/gmd-7-12972014

Kröner N, Kotlarski S, Fischer E, Lüthi D, Zubler E, Schär C (2017) Separating climate change signals into thermodynamic, lapse-rate and circulation effects: theory and application to the European summer climate. Climate Dynamics 01 5(48):3425-3440. https://doi. org/10.1007/s00382-016-3276-3

Lemke B, Kjellstrom T (2012) Calculating workplace WBGT from meteorological data. Ind Health 50:264-278. https://doi.org/10.2486/ indhealth.MS1352

Levi M, Kjellstrom T, Baldasseroni A (2018) Impact of climate change on occupational health and productivity: a systematic literature review focusing on workplace heat. Med Lav 16:E3458. https://doi.org/10. 23749/mdl.v109i3.6851

Li J, Chen YD, Gan TY, Lau N (2018) Elevated increases in humanperceived temperature under climate warming. Nature Clim Change 8:43-47. https://doi.org/10.1038/s41558-017-0036-2

Liljegren JC, Carhart RA, Lawday P, Tschopp S, Sharp R (2008) Modeling wet bulb globe temperature using standard meteorological measurements. J Occup Environ Hyg 5:645-655. https://doi.org/10. $1080 / 15459620802310770$

Matthews T (2018) Humid heat and climate change. Progress in Physical Geography: Earth and Environment 42:391-405. https://doi.org/10. $1177 / 0309133318776490$

Moda HM, Filho WL, Minhas A (2019) Impacts of climate change on outdoor workers and their safety: some research priorities. Int J Environ Res Public Health 109:163-179. https://doi.org/10.3390/ ijerph16183458

Mora C, Dousset B, Caldwell I, Powell FE, Geronimo RC, Bielecki CR, Counsell CWW, Dietrich BS, Johnston ET, Louis LV, Lucas MP, McKenzie MM, Shea AG, Tseng H, Giambelluca TW, Leon LR, Hawkins E, Trauernicht C (2017) Global risk of deadly heat. Nature Clim Change 7:501-506. https://doi.org/10.1038/nclimate3322

Morabito M, Crisci A, Messeri A, Messeri G, Betti G, Orlandini S, Raschi A, Maracchi G (2017) Increasing heatwave hazards in the southeastern European Union capitals. Atmosphere 8(7):115. https://doi.org/ 10.3390/atmos 8070115

Morris NB, Jay O, Flouris AD, Casanueva A, Gao C, Foster J, Havenith G, Nybo L (2020) Sustainable solutions to mitigate occupational heat strain - an umbrella review of physiological effects and global health perspectives. Environmental Health (in review)

NIOSH (2016) NIOSH criteria for a recommended standard: occupational exposure to heat and hot environments. U.S. Department of Health and Human Services, Centers for Disease Control and Prevention, National Institute for Occupational Safety and Health. DHHS (NIOSH) Publication 2016-106, Cincinnati

Oleson KW, Bonan GB, Feddema J, Jackson T (2011) An examination of urban heat island characteristics in a global climate model. Int J Climatol 31:1848-1865. https://doi.org/10.1002/joc.2201

Orlov A, Sillmann J, Aaheim A (2019) Economic losses of heat-induced reductions in outdoor worker productivity: a case study of Europe. EconDisCliCha 3:191-211. https://doi.org/10.1007/s41885-01900044-0

Panofsky HA, Brier GW (1968) Some applications of statistics to meteorology. Penn. State University, College of Earth and Mineral Sciences, S.l. University Park

Parlow E, Vogt R, Feigenwinter C (2014) The urban heat island of Baselseen from different perspectives. DIE ERDE - Journal of the Geographical Society of Berlin 9(145):96-110

Parsons K (2014) Human thermal environment: the effects of hot, moderate and cold temperatures on human health, 3rd edn. CRC Press, New York

Perkins SE (2015) A review on the scientific understanding of heatwaves - their measurement, driving mechanisms, and changes at the global scale. Atmos Res 164-165:242-267. https://doi.org/10. 1016/j.atmosres.2015.05.014

Pfeifroth U, Kothe S, Müller R, Trentmann J, Hollmann R, Fuchs P, Werscheck M (2017) Surface radiation data set - Heliosat (SARAH) - edn 2, Satellite Application Facility on Climate Monitoring. https://doi.org/10.5676/EUM_SAF_CM/SARAH/ V002

Piani C, Haerter JO, Coppola E (2010) Statistical bias correction for daily precipitation in regional climate models over Europe. Theor Appl Climatol 1(99):187-192. https://doi.org/10.1007/s00704-009-0134-9

Pogačar T, Casanueva A, Kozjek K, Ciuha U, Mekjavić IB, Bogataj LK, Crepinšek Z (2018) The effect of hot days on occupational heat stress in the manufacturing industry: implications for workers' 
well-being and productivity. Int J Biometeorol 62:1251-1264. https://doi.org/10.1007/s00484-018-1530-6

Posselt R, Mueller RW, Stöckli R, Trentmann J (2012) Remote sensing of solar surface radiation for climate monitoring - the CM-SAF retrieval in international comparison. Remote Sens Environ 118:186198. https://doi.org/10.1016/j.rse.2011.11.016

Posselt R, Mueller R, Trentmann J, Stockli R, Liniger MA (2014) A surface radiation climatology across two Meteosat satellite generations. Remote Sens Environ 142:103-110. https://doi.org/10.1016/j. rse.2013.11.007

Rajczak J, Kotlarski S, Salzmann N, Schär C (2016) Robust climate scenarios for sites with sparse observations: a two-step bias correction approach. Int J Climatol 36:1226-1243. https://doi.org/10. 1002/joc. 4417

Ruosteenoja K, Räisänen P (2013) Seasonal changes in solar radiation and relative humidity in Europe in response to global warming. J Clim 26:2467-2481. https://doi.org/10.1175/JCLI-D-12-00007.1

Sahu S, Sett M, Kjellstrom T (2013) Heat exposure, cardiovascular stress and work productivity in rice harvesters in India: implications for a climate change future. Ind Health 51:424-431. https://doi.org/10. 2486/indhealth.2013-0006

Schär C, Vidale PL, Lüthi D, Frei C, Häberli C, Liniger MA, Appenzeller C (2004) The role of increasing temperature variability in European summer heatwaves. Nature 22:332-336. https://doi.org/10.1038/ nature 02300

Scoccimarro E, Fogli PG, Gualdi S (2017) The role of humidity in determining scenarios of perceived temperature extremes in Europe. Environ Res Lett 12:114029. https://doi.org/10.1088/1748-9326/ aa8cdd

Smith A, Lott N, Vose R (2011) The integrated surface database: recent developments and partnerships. Bull Am Meteorol Soc 92:704-708. https://doi.org/10.1175/2011BAMS3015.1

Sørland SL, Schär C, Lüthi D, Kjellström E (2018) Bias patterns and climate change signals in GCM-RCM model chains. Environ Res Lett 13:074017. https://doi.org/10.1088/1748-9326/aacc77
Teutschbein C, Seibert J (2012) Bias correction of regional climate model simulations for hydrological climate-change impact studies: review and evaluation of different methods. J Hydrol 8(456-457):12-29. https://doi.org/10.1016/j.jhydrol.2012.05.052

UNDP (2016) Climate change and labour: impacts of heat in the workplace. S.1. issue paper. CVF secretariat, United Nations development program, Geneva. https://www.undp.org/content/undp/en/home/ librarypage/climate-and-disaster-resilience-/tacklingchallenges-ofclimate-change-and-workplace-heat-for-dev.html

Vrac M, Friederichs P (2015) Multivariate - intervariable, spatial, and temporal - bias correction. J Clim 1(28):218-237. https://doi.org/ 10.1175/JCLI-D-14-00059.1

Wilcke RAI, Mendlik T, Gobiet A (2013) Multi-variable error correction of regional climate models. Clim Chang 120:871-887. https://doi. org/10.1007/s10584-013-0845-x

Willett KM, Sherwood S (2010) Exceedance of heat index thresholds for 15 regions under a warming climate using the wet-bulb globe temperature. Int J Climatol 12(32):161-177. https://doi.org/10.1002/ joc. 2257

Wyndham CH (1969) Adaptation to heat and cold. Environ Res 2(5-6): 442-469. https://doi.org/10.1016/0013-9351(69)90015-2

Xiang J, Bi P, Pisanello D, Hansen A (2014) Health Impacts of Workplace Heat Exposure: An Epidemiological Review. Ind Health 52(2):91101. https://doi.org/10.2486/indhealth.2012-0145

Zhao Y, Ducharne A, Sultan B, Braconnot P, Vautard R (2015) Estimating heat stress from climate-based indicators: present-day biases and future spreads in the CMIP5 global climate model ensemble. Environ Res Lett 10:084013. https://doi.org/10.1088/1748-9326/ $10 / 8 / 084013$

Publisher's note Springer Nature remains neutral with regard to jurisdictional claims in published maps and institutional affiliations. 